\title{
Procurement of Functional Rural Primary School Buildings through the Application of Appropriate Technology for Building Materials and Construction
}

\author{
Japo Oweikeye Morto Amasuomo \\ Department of Vocational/Industrial Education, Faculty of Education, Niger Delta University, Wilberforce Island, \\ P. O. Box 1033, Yenagoa, Bayelsa State, Nigeria \\ japoamasuomo@gmail.com+2348033415457
}

\section{Doi:10.5901/ajis.2014.v3n1p421}

\begin{abstract}
Most rural primary schools in Ekeremor Local Government Area of Bayelsa State, Nigeria do not have buildings that are conducive for learning because the materials used for their construction are of organic origin such as thatch, mud, timber etc. This made them biodegradable and decay quickly. More frequent replacement of such materials were required because of their low durability. The functionality of such schools in terms of conducive teaching and learning environment was not assured. Appropriate technology for building materials and construction techniques was recommended as remedy.
\end{abstract}

Keywords: Appropriate technology, construction, temporary structure, building, functional

\section{Introduction}

Primary education is the first level of the education ladder or hierarchy. It is at this level that, the foundation of the whole educational edifice is laid. Therefore, any mistake made in its organization means the destruction of the entire education system (Asaya, 1996); and it is also at this level that, we cultivate the basic manpower needs of every nation (Mkpa, 1999). Various factors affect the functionality of education at the primary school level. These factors among others are inadequate supply of qualified teachers, teaching aids, library, laboratory etc which are mostly pedagogical factors.

However, this study is concerned with the problems of rural school buildings and the need to procure cost effective and functional school buildings to provide an environment that is conducive for teaching and learning. A functional school building is expected to be a permanent structure with durable building materials, and properly constructed buildings with adequate ventilation, damp-proof floors, plastered and painted walls with ceiling finishing. To provide a low cost functional rural school building therefore require the application of appropriate technology for the production of materials from available local raw materials and construction techniques using the available rural labour.

\subsection{Problems with rural school buildings}

From available data on rural primary school buildings in Bayelsa State, Nigeria, about $53 \%$ of the schools operate from temporary structures (Amasuomo, 1999). These temporary structures used as school buildings are constructed with thatch or zinc roofs, mud or locally sawn and untreated timber walls, and mud floors that are usually damp especially during the rainy seasons. Because, the building materials are of organic origin (Parry, 1980), they deteriorate quickly and do not maintain their form for very long period. Also, most traditional building materials used for such buildings are poor in durability and therefore require frequent replacement than modern building materials such as sandcrete blocks, long span aluminium and asbestos roofing sheets (Obande, 1990). The expected durability period of such materials is between 3-5 years (Parry, 1980).

There are other materials used for the construction of these temporary classroom structures and the problems associated with them are enormous. Where thatch (a leaf got from raffia palm tree) is used as roof and wall covering material, a double health hazard is expected. They provide a perfect shelter and breeding place not only for vermin, rats, cockroaches, etc, but also for various blood sucking vectors of such diseases as sleeping sickness (Parry, 1980). Thatch is a degradable material, it leaks frequently during rains, and rot away after a few years, and can easily catch fire because it has very little resistance to fire.

Mud walls are derived from clay soil, and when used for wall construction, it is prone to shrinkage, erosion and under-scouring especially when exposed to direct sunlight and subjected to well defined periods of sunshine and rainfall 
(Obande, 1990). Timber, when used for wall construction and is exposed to rain is easily soaked with water. In few years, they decay and fall off the walls since most rural timbers used for construction are neither seasoned nor treated with preservatives. Timber sometimes is also used for the construction of floors raised on stilts in areas prone to flooding.

Most rural school building floors are finished with mud and usually damp especially during the rainy season. Dampness could affect the health of the teachers and the pupils. And the pupils in most cases do not put on foot wears such as sandals or shoes. Therefore, their feet are always in direct contact with the damp floors.

\subsection{Factors militating against the provision of comfortable school buildings in rural areas}

There are basically three factors that militate against the provision of functional and cost effective rural school buildings. These are the absence of required conventional building materials in the rural areas; cost of transporting heavy building materials for long distances especially in the riverine areas; and the absence of available skilled labour in rural areas that can carry out modern building construction.

From the foregoing, measures designed to reduce the purchase of heavy building materials from urban centres became increasingly important since the farther away a building site is from the point of supply, the more costly it is to procure buildings in the rural areas. Therefore, the cost of providing rural school buildings by government according to Parry (1980) is a special constraint; and as a result of the unacceptable high cost of construction using conventional standards in remote centres, public amenity buildings are frequently not put up at all, a factor which contributes to the deprivation of many rural areas. To remedy this problem, the application of appropriate technology in building materials and construction is the rescue.

\subsection{Purpose of the study}

The specific objectives of this study is to ascertain:

1. The availability of materials for the manufacture of building materials in the rural areas through appropriate technology.

2. The appropriate technologies available for the manufacture of building materials for rural school building procurement.

3. The appropriate construction methods available that is different from the conventional standards for building procurement.

4. The cost effectiveness of rural school building procured through appropriate technology as compared with the convention standards.

\section{Methodology}

The study area is Ekeremor Local Government Area of Bayelsa State, Nigeria. It is a riverine area criss-crossed by my rivers and streams. There are no motor-able roads; transportation is by engine boats or locally dug -out canoes; and this has made transportation difficult and costly. It is located between latitudes $4^{\circ}$ and $2^{0}$ North and South respectively, and longitudes $2^{0}$ and $6^{\circ}$ East and West respectively. It is influenced by the Tropical Sub-Equatorial climate. The climate is characterized by high temperature of $28^{\circ} \mathrm{C}$ to $31^{\circ} \mathrm{C}$ with high relative humidity of about $75 \%$ and over $3050 \mathrm{~mm}$ of rainfall (Evans, 1979; Angaye and Okpara, 1981 and Balogun, 2000). It is also characterised by rain, fresh water swamp and mangrove swamp forests. The high relative humidity and rainfall encourages dampness, and provides a breeding ground for termites, fungi etc, and this makes building materials deteriorate fast. There are seventy-one primary schools in the Local Government Area, and twenty (20) of them representing $28 \%$ are built with conventional standards for building materials and construction while fifty (51) schools representing $72 \%$ are in temporary structures. This statistics indicated that, the local government lacked functional primary school buildings for effective teaching and learning.

\section{Research Findings}

\subsection{Availability of raw materials and their products}

The available raw materials presented in Table 1 which can be harnessed to produce building materials through the application of appropriate technology are clay soil, river sand, river gravel, grasses, water hyacinth, raffia palm, periwinkle 
shells, palm kernel shells, timber.

Table 1: Available raw materials and their products

\begin{tabular}{|c|c|}
\hline \multicolumn{2}{|c|}{ Available raw materials Products } \\
\hline Clay soil & Brick walls, bidding material for wall construction and wall finishing \\
\hline River sand & Roof covering, brick walls, foundation concrete and mortar for wall bonding \\
\hline River gravel & Aggregate for concrete and floor finish \\
\hline $\begin{array}{l}\text { Grasses, tree leaves } \\
\text { and water hyacinth }\end{array}$ & Fibre for producing roof covering and un-burnt bricks. \\
\hline Raffia palm fibre & Fibre for the manufacture of roof covering and un-burnt bricks \\
\hline Palm kernel shells & Aggregate for concrete and floor finish \\
\hline Periwinkle & Aggregate for concrete and floor finish \\
\hline Palm fruit fibre & Fibre for the manufacture of roof covering and un-burnt bricks. \\
\hline Palm tree fibre & Fibre for the manufacture of roof covering and un-burnt bricks \\
\hline Timber & For roof trusses, and construction of doors and windows \\
\hline
\end{tabular}

Source: Author's field strip

These raw materials are in abundant supply in their natural form. The only manufactured products required from the urban centre are Portland cement and moulds for the manufacture of corrugated roofing sheets.

\subsection{Appropriate technology for production of building materials}

The various methods of producing functional and cost effective building materials for rural school procurement is divided into roof covering, walling materials, aggregates and binding materials. The need to use appropriate technology in the production of building materials for rural buildings is to ensure that materials so produced are durable.

\subsubsection{Roof covering}

Low cost roofing materials in rural areas is produced from fibre reinforced cement-sand roofing sheets. It is manufactured by sieving sand to fine grain size of $2 \mathrm{~mm}$. Fibres from grass, water hyacinth, tree leaves, raffia palm, palm tree, palm kernel fruit are chopped to required sizes. Then cement, sand and the fibres are mixed to together with water using spade or shovel. The mix when in a plastic state is poured into a corrugated mould and compacted by stamping. After treating the surface with a wooden trowel, the product and mould is transferred and stacked for 24 hours where primary curing takes place. Secondary curing which lasts for 7 days is carried out by packing the products one on top of the other (Parry, 1980; and Person and Skaredahl, 1980).

\subsubsection{Walling material}

The clay bricks of $285 \mathrm{~mm}$ length, $115 \mathrm{~mm}$ width and $135 \mathrm{~mm}$ high (Mundi, 1980) is produced from the abundant clay soil that is available. Un-burnt bricks are recommended here because of cost of energy to fire it. The un-burnt brick is produced by stabilizing clay with fibre and some cement. Water is added to the mix until it gets close to its plastic limit. The mix is deposited into a mould of wooden or steel boxes, and levelled off with a straight edge. The mould is then removed, leaving the clay bricks or blocks behind, and then allowed to cure slowly and dried naturally for 7 days. This type of block or brick wall is impact resistant (Parry, 1980) and has a resistance to fire.

\subsubsection{Materials for foundation}

Materials such as river gravel, crushed palm kernel shells and periwinkle shells whichever one is in abundant supply is sourced and mixed with cement and sand as concrete material. These materials are not in short supply in this area.

\subsubsection{Binding materials}

The binding material to bond the bricks or blocks together while building the walls is produced from clay soil stabilized 
with sand or cement; or sand-cement mortar mixed with water to a plastic state. But where clay soil only is used, it should be pointed with cement-sand mortar of 1:4 mix ratio (Visvesvaraya, 1980).

\subsection{Appropriate technology for building construction}

The use of locally available materials and the adoption of improved construction practices through appropriate technology is the only means of providing durability rural primary school buildings since the use of conventional construction that conforms to best practices attract huge cost. Appropriate technology for construction methods can be applied to foundation, walls, finishing, roof structures and covering, lintels, floors and floor finishing; and door and window construction.

\subsubsection{Foundation}

The foundation is normally constructed by excavating trench of width not more than $450 \mathrm{~mm}$ and a depth not more than $600 \mathrm{~mm}$ to avoid the effect of ground water when the ground water table becomes high during the rainy season period. Where the un-burnt bricks or blocks are used, the length of the brick or block should be placed at right angle to the length of the foundation excavation to form the base. The bricks or blocks should be bonded together with either cement stabilized clay binder or sand stabilized binder. In the alternative, where brick is not used as foundation base, river gravel, periwinkle or palm-kernel shells can be used by mixing them with sand and cement in appropriate ratio to produce concrete for foundation.

\subsubsection{Walls}

The walls are constructed by placing the locally produced un-burnt clay bricks or blocks along the centre-line of the foundation base allowing some projection of the foundation footing on both sides of the building walls. The bonding material for the walls could be clay soil binder mixed with water to a plastic state and used for the bonding. To attain adequate strength, binders are stabilized with cement. Where only clay mud binder is used, the wall should be pointed with cement mortar.

\subsubsection{Wall finishing}

A $15 \mathrm{~mm}$ thick layer of clay is used as plaster for the internal walls. The clay that is stabilized with some cement and mixed with water to near liquid limit is applied to the wall and rubbed smooth with hand or trowel.

\subsubsection{Roof structure}

The roof trusses are constructed with sawn timber with a king post and closely provided struts. The timber should be seasoned and preserved by painting it with insecticides. Wire nails are used as fasteners.

\subsubsection{Roof covering}

The cement-sand-fibre reinforced corrugated roofing sheets are fixed to appropriate purlins with zinc nails. Roofs should have over-hang of about $1200 \mathrm{~mm}$ to protect the walls from the effect of rain water.

\subsubsection{Lintels}

In providing lintels, the span should not exceed the opening sizes for doors of $750 \mathrm{~mm}$ to $900 \mathrm{~mm}$ wide; and window opening not exceeding $1200 \mathrm{~mm}$. It should be designed for use only where the crack widths can be kept to a low level (Person and Skarendahl, 1980). Locally available timber planks of sufficient thickness can be used but covered with fibre reinforced mortar. 


\subsubsection{Floors}

The floor soil should be stabilized with some cement and well compacted, rendered dust free and raised relatively above the ground level. After properly ramming the earth, it may be finished with river gravel, palm kernel shells or periwinkle shells which are rammed into the earth.

\subsubsection{Doors and windows}

Sawn timber which is readily available is used to produce the simplest form of door and window construction. The batten and braced timber doors and windows can be produced by both skilled and semi-skilled carpenter.

\subsection{Comparative cost between appropriate technology and conventional building procurement methods}

Table 2 shows a comparative cost between the application of appropriate technology and the conventional methods of building procurement. Data in the table indicated that, there was a lot of savings in the cost of procuring buildings through the application of appropriate technology. The savings in cost ranges between 8 and $28 \%$ depending on the type of materials used and the method of construction.

Table 2: Cost comparison between appropriate technology and conventional building procurement methods

\begin{tabular}{ll}
\hline Building element & Average percent savings in cost (\%) \\
\hline Foundations & 28 to 38 \\
Floors & 8 to 20 \\
Walling & 14 to 25 \\
Roofing and roof covering & 8 to 20 \\
Doors and windows & 10 to 20 \\
Lintels & 20 to 40 \\
Floor and wall finishing & 10 to 15 \\
\hline
\end{tabular}

Source: De, Gupta, Mangal, Moham, Rai, Sharma, and Verma, (1980)

\subsection{Advantages of appropriate technology for building materials and construction}

The application of appropriate technology in the production of building materials and construction methods in the procurement of functional and cost effective rural primary school buildings has the following advantages:

1. Very little transport is required to convey the constituent raw materials.

2. It uses the cheap local labour that is readily available in the rural areas.

3. The equipment for production of building materials is simple and cheap

4. Electricity and elaborate use of fuel is not required.

5. Machinery is not required.

6. Limited knowledge is required.

\subsection{Reasons why appropriate technology is not yet accepted by rural communities}

Despite the relative low cost of procuring functional rural primary school buildings through the application of appropriate technology for building materials and construction, its use is yet to be accepted. The reasons for the non-popularity of appropriate technology are as follows:

1. Inadequate publicity of research outcomes and the expected beneficiaries of such research works are not adequately informed.

2. There are no training programmes carried out in the rural areas on the techniques of producing building materials and their construction methods.

3. Government has not demonstrated the importance of these research outcomes by using the technologies in their building projects. Instead, government still uses the conventional techniques and materials in all their 
building projects.

\section{Conclusion}

Conventional techniques and materials for building construction have been found to be costly. This has been attributed to transportation cost of conveying bulk purchases of materials, and the importation of skilled labour from the urban centres. These factors have contributed to the inability of government to provide public amenities such as rural primary school buildings especially in the remote areas. The inability of government to provide rural amenities has also deprived the rural primary school pupils of functional classroom accommodation devoid of health and safety risks. Invariably, the effect of not having conducive teaching and learning environment on functional primary education is enormous. This is because, effective learning is not likely to take place in a classroom environment that is constructed with temporary structures since these structures require more frequent replacement due to their low durability. The only means of procuring affordable and habitable classroom buildings for functional primary education in the rural areas is therefore through the application of appropriate technology in building materials and construction.

\section{References}

Amasuomo, J. O. M. (2001). The government and community participation in primary education: What legacy for quantitative primary and technology teacher education. Teachers. In B. J. Obomanu (Ed) Trends in Technology Teacher Education in Nigeria. Omoku, Nigeria: Federal College of Education (Technical). 354 - 365.

Angaye, S. M. S and Okpara, C. E. (1981). School atlas for Rivers State of Nigeria. Macmillan Education Ltd, London

Asaya, S. A. (1996). Problems and prospects of quality control of Nigerian primary education. Obudu Journal of Educational Studies. Federal College of Education, Obudu, Nigeria, 2(2), 15-19.

Balogun, O. (2000). Senior secondary atlas. Longman Nigeria Ltd, Ikeja- Lagos:,

De, P. L; Gupta, T. N; Mangal, R. C; Moham, D; Rai, K; Sharma, J. S; and Verma, N. (1980). appropriate industrial technologies and materials for housing and building in India, In Appropriate Industrial Technology for Construction and Building MaterialsMonograph, No. 12, UNIDO, Vienna.

Evans, M. (1997). Tropical design. In P. Tutt and D. Adler (Eds.). New metric Handbook. London: Butterworth-Heinemann, London 402411

Mkpa, M. A. (1999). Challenges of primary and secondary education in the $21^{\text {st }}$ century Nigeria. Lead paper presented at the Maiden National Conference on Primary and Secondary Education, School of Education, Federal College of Education (Technical), Umunze, Nigeria. $1^{\text {st }} 4^{\text {th }}$ September.

Mundi, E. K. (1980). Construction and building materials industry in the united republic of Cameroon. In Appropriate Industrial Technology for Construction and Building Materials- Monograph, No. 12, UNIDO, Vienna.

Obande, M. O. (1990). Block laying and concreting. Longman Nigeria Ltd, Ikeja-Lagos:

Parry, J. M. P. (1980). Building materials and components In Appropriate Industrial Technology for Construction and Building MaterialsMonograph, No. 12, UNIDO Vienna.

Person, H. and Skarendahl, A. (1980). Sisal- fibre concrete for roofing sheets and other purposes. In Appropriate Industrial Technology for Construction and Building Materials- Monograph, No. 12, UNIDO Vienna.

Visvesvaraya, H. C. (1980). Strategies for development of cement and allied industries in developing countries. In Appropriate Industrial Technology for Construction and Building Materials- Monograph, №. 12, UNIDO Vienna. 